\title{
PENDAMPINGAN APLIKASI RAPOR DIGITAL DI MADRASAH IBTIDAIYAH MIFTAHUL JINAN WONOAYU SIDOARJO
}

\author{
Sufinatin Aisida', Safi'il Anam \\ Universitas Sunan Giri Surabaya
}

\begin{abstract}
ABSTRAK
Pendampingan pelatihan Aplikasi Rapor Digital ini berupaya untuk memberikan bantuan terhadap para guru dilingkungan MI dan RA Miftahul Jinan, agar mampu mengikuti tututan pemerintah dan kecepatan arus teknologi untuk mempermudah dalam mengakses data nilai peserta didik dan tersimpan secara digital dan rapi baik di lembaga sendiri maupun di kementrian Agama. Pelatihan Aplikasi Rapor Digital ini dilakukan dengan menggunakan penelitian kualitatif dengan menggunakan pendekatan Participatory Action Reaserch (PAR), Data penelitian ini dikumpulakan melalui teknik obervasi lapangan, Focus Grup Discussion (FGD), wawancara dan tekhnik dokumentasi, tes. meliputi reduksi data, penyajian data dan pencarian kesimpulan . Dengan tujuan agar para peserta memahami dan mampu melakukan aplikasi rapor digital secara maksimal. Hasilnya menunjukkan bahwa rata-rata skor pre test sebesar 60,6 , dan nilai post test menunjukkan bahwa rataratanya sebesar 72,5. Hal ini dapat diambil sebuah kesimpulan bahwa terdapat peningkatan sebesar 11,9 dan di dapatkan N-Gain sebesar 0,3 dengan kategori sedang. Hal ini menunjukkan bahwa mayoritas peserta pelatihan mengalami peningkatan dalam hasil tesnya.

Kata Kunci: Aplikasi Rapor Digital, Madrasah Ibtidaiyah

\section{ABSTRACT}

This Digital Report Card Application training assistance seeks to provide assistance to teachers in the environment MI Miftahul Jinan, in order to be able to follow government demands and the speed of technology flows to make it easier to access student value data and stored digitally and the speed of technology flow to make it easier to access student value data and stored digitally and the speed of technology flow to make it easier to access student value data and stored digitally and neatly both in the institution itself and at the Ministry of Religion, Digital Report Card Application training his is done by the lecture method, varieswith discussion and question and adswer, demonstrations and assignments, With the aim that the participant understand and able to do digital report cars applications optimally. The results showe that the pre-test average score was 60.6 , and the post-test value show that the average is 72,5 . It can be concluded that there is category. Based on the results, it shows that the majority of training particants experienced an inrease in their test results.

Keywords: Digital Report Card Application, Madrasah Ibtidaiyah
\end{abstract}

\section{A. Pendahuluan}

Teknologi tidak dapat dipisahkan dalam kehidupan manusia dengan dunia pendidikan, kemajuan dalam bidang teknologi dan informasi memberikan pengaruh positif maupun negatif bagi dunia pendidikan. Selain dari segi efektivitas dan efisiensi, penggunaan teknologi selain merambah dunia pembelajaran dalam bidang pendidikan, juga merangkak naik menunju pembuatan rapor bagi wali kelas, kecanggihan teknologi 
ini tidak dapat dihindari karena derasnya arus informasi dan kecanggihan tenologi berbasis ICT membuat sekolah berdampak pada pembuatan rapor digital.

Selain itu, tugas lain yang menunggu di antaranya adalah mendidik, mengajar, membimbing, mengarahkan, melatih, menilai serta mengevaluasi hasil kinerja para peserta didiknya dengan tujuan akhir adalah agar menghasilkan sumberdaya manusia yang memiliki kualitas yang representatif dan mampu bersaing dengan lembaga lainnya. Kompetensi lain yang tidak dapat ditinggalkan adalah kemampuan para guru untuk melek informasi, tuntutan untuk mampu menggunakan raport digital menjadi sebuah tuntutan zaman yang tidak dapat dihindarkan. Termasuk lembaga dibawah naungan Yayasan Miftahul Jinan yang meliputi: Madrasah Ibtidaiyah Miftahul Jinan Wonoayu Sidoarjo. Sekolah yang berada dalam naungan Kementerian Agama RI kabupaten Sidoarjo ini juga dituntut untuk menggunakan Aplikasi Raport Digital (ARD).

ARD adalah aplikasi pelaporan hasil belajar siswa Madrasah Ibtidaiyah berbasis daring yang dimiliki oleh Madrasah yang berada di bawah naungan Kementerian Agama RI. Penggunaan Aplikasi Rapor Digital mulai diimpleetasikan sejak tahun 2018/2019 pada jenjang madrasah ibtidaiyah Implementasi ARD menjadikan proses pencatatan dan pelaporan data evaluasi belajar siswa menjadi lebih efisien serta terecord dalam sistem basis data pendidikan yang dimiliki oleh Kementerian Agama. Implementasi ARD memungkinkan guru mengetahui nilai akhir, KKM, rerata, dll tanpa proses penghitungan secara manual. Di sisi lain, implementasi ARD menghendaki kesiapan sumber daya manusia guru dan operator ARD madrasah yang memiliki kompetensi literasi komputer, teknologi informasi serta kemampuan untuk memanfaatkan potensi yang dimiliki. ${ }^{1}$

Teknologi Informasi ini tentunya diharapkan bisa meningkatkan mutu pendidikan, lebih efisien, serta sangat efektif dan terakhir adalah hasil proses belajar mengajar dapat lebih maksimal. Pendidikan merupakan bagian terpenting dalam kehidupan manusia sehari-hari, karena dengan adanya pendidikan manusia akan merasakan bagaimana hidup di dunia ini dengan ilmu pengetahuan. Pendidikan merupakan dimensi yang memiliki sistem kerja yang akan membantu manusia yang dasarnya tidak mengetahui menjadi mengetahui dan mengerti, dimensi tersebut meliputi aspek visi, 5 misi, tujuan, kurikulum, bahan ajar, pendidik, peserta didik, sarana prasarana dan lingkungan yang efektif. ${ }^{2}$

\footnotetext{
${ }^{1}$ Novan Ardy Wiyani, “Kompetisi dan Strategi Pengembangan Lembaga PAUD Islam Berdaya Saing di TK Islam Alirsyad Banyumas", dalam Jurnal Manejemen Pendidikan Islam, Vol.1, No. 1, (2016).

${ }^{2}$ Abuddin Nata, Ilmu Pendidikan Islam (Jakarta: Kencana Prenada Media Group. 2010), 90.
} 
Oleh karena itu Madrasah Ibtidaiyah dan RA Miftahul Jinan yang ada di kecamatan Wonoayu ini, berbena diri untuk mengikuti peraturan pemerintah dan peningkatan SDM, dengan mulai menerapkan penggunaan ARD, dimana awalnya madrasah ini tidak menggunakan rapor digital tetapi menggunakan raport manual atau ditulis dengan menggunakan bolpoin. karena perubahan kebijakan pemerintah yang masih belum sepenuhnya dilaksanakan oleh masing-masing madrasah ibtidaiyah di lingkungan kecamatan Wonoayu, maka dari itu secara bertahap mulai mengikuti kebijakan pemerintah tersebut, meskipun masih belum seluruhnya dapat terealisasi, karena banyaknya faktor penghambat diantaranya adalah kemampuan SDM yang ada. Oleh karena itu madrasah ibtidaiyah Miftahul Jinan dan RA Miftahul Jinan di wilayah kecamatan Wonoayu Sidoarjo merasakan dampak tersebut, termasuk SDM yang hampir seluruhnya belum mengikuti ARD, sehingga amat diperlukan Pendampingan aplikasi rapor digital ini dengan segera karena mendesaknya kebutuhan dan tuntutan lembaga dan pemerintah. Oleh karena itu tim pengabdian kepada masyarakat mengadakan pendampingan pelatihan aplikasi rapor digital dengan tujuan agar guru-guru di MI dan RA Miftahul Jinan mampu mempersiapkan diri dalam menyambut era digital dengan adanya Aplikasi Raport Digita, terutama para wali kelas yang secara langsung terkena imbas tersebut.

ARD madrasah merupakan salah satu implementasi dari juknis Penilaian Hasil Belajar pada Madrasah Ibtidaiyah (SK Dirjen Pendis Nomor 5162 Tahun 2018). Adanya ARD ini tidak lain adalah untuk meningkatkan layanan kepada orang tua atau wali murid untuk mengakses informasi yang berkelanjutan mengenai perkembangan anak dari waktu ke waktu. Rapor tersebut juga digunakan untuk merekam evaluasi peserta didik sesuai dengan Nomor Induk Siswa Nasional (NISN) untuk tiap jenjang pendidikan. Dengan adanya ARD semua guru akan melek informasi dan melek teknologi, pada awalanya pasti merasa berat karena sesuatu yang baru dan belum pernah dikenal, tetapi seiring dengan tuntutan dan kebiasaan yang dilakukan secara rutin pasti akan membuahkan hasil yang diharapkan dan demi kemajuan lembaga bersama.kemunculan ARD menuntut madrasah harus semakin maju dan terbuka terhadap dunia internet dan digital. Cepatnya arus informasi terutama bagi siswa madrasah, untuk mencapai target kinerja sekaligu memenuhi harapan publik. ARD merupakan aplikasi yang digunakan untuk menyusun laporan penilaian terhadap pencapaian kompetensi peserta didik pada satuan pendidikan madrasah selama dua semester. 
Kegiatan Pendampingan ini direncanakan akan dilaksanakan dengan proses penyampaian materi oleh narasumber sekaligus langsung diajak praktik pembuatan ARD, karena itulah peserta pelatihan ARD wajib membawa laptop masing-masing sehingga dapat langsung mengaplikasikan apa yang narasumber sampaikan. Diharapkan dari pelatihan ini para wali kelas dan guru mampu membuat rapor digital secara maksimal.

\section{B. Metode Penelitian}

\section{Jenis Penelitian}

Metode penelitian dari jenis data penelitian ini adalah penelitian kualitatif dengan menggunakan pendekatan Participatory Action Reaserch (PAR) untuk mencapai kondisi yang diharapakan. PAR merupakan salah satu jenis penelitian kualitatif yang melibatkan tindakan peneliti dan anggota masyarakat dalam hal ini masyarakat atau organisasi yang berusaha untuk memperbaiki situasi mereka. ${ }^{3}$ Menurut Chevalier \& Bukles PAR mengintegrasikan tiga komponen penting yaitu partispiasi (participation), tindakan (action), dan penelitian (research) sebagai upaya memberikan konstribusi dalam proses menemukan solusi perubahan sistem social (komunitas) untuk bertindak berdasarkan faktor-faktor kompleks yang berpengaruh pada ketidak berdayaan hidup yang tidak manusiawi. PAR berakar pada prinsip-prinsip inkulsi (desain penelitianya melibatkan orang, proses dan hasil), adanya partisipasi; menghargai semua pendapat komunitas; adanya hasil pada perubahan yang berkelanjutan. ${ }^{4}$

\section{Teknik Pengumpulan Data Penelitian}

Data penelitian ini dikumpulakan melalui teknik obervasi lapangan, Focus Grup Discussion (FGD), wawancara dan tekhnik dokumentasi, tes.

\section{Teknik Analisis Data}

Teknik analisis data dalam penelitian terdiri dari alur kegiatan yang terjadi secara bersamaan meliputi reduksi data, penyajian data dan pencarian kesimpulan. Adapun penarikan kesimpulan diperoleh dari kegiatan rekflesi sebagai proses analisa akhir dari hasil perolehan data otentik dan lapanagan untuk mendalami kebutuhan masyarakat yang menjadi sasaran utama dampingan sehingga dapat memenemukan strategi pemberdayaan.

3 C. Mackdonald, "Understanding Participatory action research: a qualitative research methodology option, canadian journal of action research", Vol.13 No.2 (2012): 34-50.

4 H. Kidwai, Et., al., (Eds.), Participatory action research and educational development: South Asian perspectives (Palgrave Macmillan: Springer, 2017). 


\section{Hasil dan Pembahasan}

\section{Madrasah Ibtidaiyah Miftahul Jinan}

Adalah salah satu madrasah yang memiliki jumlah murid terbanyak ke dua diantara $18 \mathrm{Ml}$ yang ada di kecamatan Wonoayu yang berada dikabupaten Sidoarjo, MI yang memiliki akreditasi A ini memiliki jumlah siswa mencapai 208 peserta didik, dengan dewan guru 15 orang, mampu bersaing secara baik mengikuti perkembangan zaman tidak terkecuali dibidang ilmu pengetahuan dan teknologi. Dan RA Miftahul Jinan dengan jumlah guru 6 orang. Semua Guru baik di MI maupun di RA adalah berstatus sarjana S-1 bahkan 2 orang dari guru MI bergelar M.Pd.I sedangkan guru RA satu (1) orang berstatus PNS dan satu (1) orang guru MI berstatus PNS. ${ }^{5}$

Diera digital inipun Madrasah Ibtidaiyah dan RA Miftahul Jinan terus berbenah diri dan berupaya untuk berpacu agar tidak tertinggal dengan sekolah lain termasuk dalam aplikasi rapor digital, oleh karena itu upaya yang dilakukan lembaga agar semua wali kelas dan dewan guru, operator agar semuanya mampu mengaplikasikan rapor digital secara mandiri dan tidak bergantung pada guru atau walikelas lainnya bahkan kepada lembaga lain.

MI dan RA Miftahul Jinan terletak di lokasi yang sangat strategis, berada ditengah permukiman masyarakat desa semambung, berdampingan dengan Majid Baitul Muttaqien, berjarak $500 \mathrm{mtr}$ dengan balai desa Semambung, berjarak $1 \mathrm{Km}$ dengan Kecamatan Wonoayu, berdampingan dengan SDN 1 di Semambung dengan jarak 500 mtr. $^{6}$

Berdasarkan kondisi kondisi dan potensi yang dimiliki oleh kedua lembaga tersebut serta potensi wilayah sekitar lembaga MI dan RA Miftahul Jinan, sangat potensial untuk diupayakan pendampingan dalam Aplikasi Rapor Digital (ARD).

\section{Teknologi Digital}

Salah satu syarat guru profesional di era digital, adalah seorang guru yang selain memiliki kompetensi pedagogik, kepribadian, sosial dan profesional sebagaimana telah disebutkan di atas, juga harus memiliki wawasan, ketertarikan, kepedulian, kepekaan, kesukaan, serta kemampuan dan keterampilan dalam menggunakanteknologi digital. Beberapa hal yang patut dijadikan pertimbangan diantaranya adalah:

\footnotetext{
${ }^{5}$ Kepala RA Miftahul Jinan, Wawancara, Sidoarjo, 02 Juli 2020.

${ }^{6}$ Kepala Mi Miftahul Jinan, Wawancara, Sidoarjo, 02 Juli 2020. 
Pertama, dalam masalah mutu pendidikan, Indonesia jauh tertinggal dibandingkan dengan mutu pendidikan di negara-negara lain. Di antara sebab ketertinggalnya ini karena rendahnya mutu tenaga guru, dan di antara sebab rendahnya mutu guru dalam hal wawasan, ketertarikan, kepedulian, kepekaan, kesukaan, serta kemampuan dan keterampilan dalam menggunakan teknologi. Beberapa negara, seperti Mynmar, Singapura, Vietnam, Filipina, Brunnei Darussalam, Thailand, Malaysia. Pada tahun 2003, atau 14 tahun yang lalu, Mynmar telah menetapkan penggunaan teknologi komunikasi dan informasi sebagai bagian dari 10 butir kebijakan pada pendidikan dasar. Sementara itu pada jenjang perguruan tinggi ada 36 program yang terfokus pada 6 kawasan, yaitu pengembangan sumber daya manusia, penggunaan teknologi, penelitian, masyarakat belajar sepanjang hayat, peningkatan mutu pendidikan dan pelestarian nilai-nilai dan identitas nasional. Demikian pula Singapura, sejak tahun 1997 telah menetapkan untuk membawa bangsanya menjadi bangsa yang berfikir dan memeliki warga negara yang siap serta mampu memberikan kontribusi bagi perkembangan dan kesejahteraan Singapura. Untuk itu teknologi komunikasi dan informasi, dengan penekanan pada komputer, tidak lagi pada radio dan TV, digunakan secara luas untuk mengembangkan kemampuan komunikasi dan belajar mandiri. Program-program berbasis komputer telah digunakan di sekolah untuk mempersiapkan siswa-siswa menghadapi tantangan abad 21.

Kedua, bahwa teknologi digital memiliki berbagai fungsi yang relevan untuk diintegrasikan ke dalam kegiatan belajar mengajar. Sudarno Sudirdjo dan Eveline Siregar dalam Mozaik Teknologi Pendidikan, ${ }^{7}$ misalnya menyebutkan 8 fungsi dari teknologi pembelajaran termasuk digital yaitu (1)memberikan pengetahuan tentang tujuan belajar; (2)memotivasi siswa; (3)menyajikan informasi; (4)merangsang diskusi, (5)mengarahkan kegiatan siswa; (6)melaksanakan latihan dan ulangan, (7)menguatkan belajar, dan (8)memberikan pengalaman simulasi.

Sedangkan Damian Ryan dalam Understanding Digital Marketing (1997:151) mengatakan:

Social media is the umbrella term for web based software and servixe that allow used to come together online and exchange, discuss, communicates and participate in any form of social interaction. That interaction cam encompass text, audio, images, video, and other media, individually or in any combanion. It can involved the generation of nw contents, the recommendation of and

7 Soetjipto dan Raflis Kosasi, Profesi Keguruan (Jakarta: Rineka Cipta dan Pusat Perbukuan Depdiknas, 2009), cet. IV, 15-16. 
sharing of existing content; reviewing and rating products, sevices and brands discussing the ht topics of the day; pursuing habbies, internets, and passions, sharing experience and expertise. In factm almost anything, that law be distributed and shared through digitak channels in fair game. ${ }^{8}$ Artinya: Media sosial adalah sebuah istilah yang memayungi web yang berbasis pada perangkat lunak dan pelayanan yang membolehkan pada pengguna untuk datang bersamasama pada online dan tukar menukar informasi, diskusi, komunikasi dan partisipasi dalam berbagai bentuknya yang terdapat dalam interaksi sosial. Interaksi tersebut, dapat mendorong penggunaan bahan bacaan, pendengaran, khayalan, vedio dan media lainnya, secara individual atau gabungan. Teknologi juga dapat menjangkau generasai pada isi yang baru, saran dan masukan untuk saling tukar menukar informasi, menilai dan menata ulang suatu produk, pelayanan dan pendelegasian, mendiskusikan tentang berbagai topik harian, meningkatkan gememaran, daya tarik dan passion, tukar menukar pengalaman dan keahlian. Faktanya, semua hal tersebut dapat didistribusikan and dikerjasamakan melalui jaringan teknologi digital sebagai permainan yang adil.

Ketiga, bahwa teknologi digital merupakan sebuah proses revolusi yang mau tidak mau harus dijalani. Alvin Toffler misalnya membagi masyarakat ke dalam masyarakat agraris (agricultural society), masyarakat industri (industrial sociey) dan masyarakat informasi (informatical society).Masyarakat agraris ditandai oleh pola hidup yang berorientasi pada masa lalu, kurang menghargai waktu, bekerja tanpa perencanaan, komunikasi secara face to face, ukuran kekayaan pada tanah dan hewan ternak, dan menggunakan teknologi sederhana yang bisa didaur ulang (recycle) dengan alam secara cepat. Sedangkan masyarakat industri, ditandai oleh pola hidup yang berorientasi pada masa depan, sangat menghargai waktu, bekerja dengan perencanaan, komunikasi jarak jauh, ukuran kekayaan pada penguasaan mesin industri, dan menggunakan teknologi canggih yang sulit didaur ulang. Sementara itu, masyarakat informasi, selain ditandai oleh ciri-ciri masyarakat industri juga ditandai oleh penggunaan teknologi penerima, penyimpan, pengolah dan pengirim data yang canggih (komputer dan laptop, dan kini teknologi digital yang dapat memainkan peran melebihi kemampuan komputer dan laptop dalam berbagai aspeknya. ${ }^{9}$ Dunia pendidikan di Indonesia saat ini, nampaknya harus melayani ketiga model masyarakat tersebut. Melayani model masyarakat agraris lebih mudah dibandingkan menghadapi masyarakat industri, dan menghadapi masyarakat informasi lebih sulit dibandingkan dengan menghadapi masyarakat industri. Hadirnya ketiga model masyarakat ini, akan merubah paradigma yang mendasari berbagai komponen pendidikan. Konsep belajar mengajar pada masyarakat informasi bukan lagi dengan cara transfer of knowedge

8 Damian Ryan, Understanding Digital Marketing, Marketing Strategies for Engaging The Digital Generation (London, Philadelphia New Delhi: Kogan Page, 2014).

${ }^{9}$ Alvin Toffler, The Third Wave (New York: William Morrow and Company, Inc, 1980), 312-330. 
atau transfer of skill, melainkan lebih ditekankan pada menggerakan, memotivasi, menjembatani, memfasilitasi, agar peserta didik tergerak melakukan berbagai kegiatan guna memperoleh pengetahuan yang dikehendakinya yang selanjutnya diberikan penguatan, pengayaan, atau perbaikan oleh guru. Demikian pula paradigma yang mendasari konsep kurikulum dan silabus, sumber bahan ajar, lingkungan dan evaluasi pendidikan juga mengalami perubahan, dan semua harus berbasis sesuai keadaan masyarakat. Jika selama ini para guru terbiasa bertugas melaksanakan pekerjaan profesionalnya dengan paradigma pendidikan yang berbasis masyarakat agraris dan industri, maka saat ini, para guru harus melaksanakan pekerjaan profesionalnya dengan paradigma pendidikan yang berbasis informasi digital. Merubah paradigma dari agraris ke industri, dan dari industri ke informasi, bukanlah pekerjaan yang mudah karena selain membutuhkan perubahan sikap mental, mindset, pola pikir, paradigma, juga membutuhkan sarana prasarana, biaya dan lain sebagainya. Dalam konteks ini, para guru harus siap untuk berani keluar dari kebiasaan lama (out of the box).

Keempat, bahwa dilihat dari segi fungsinya, teknologi digital selain dapat bekerja lebih cepat, juga dapat menjangkau wilayah yang lebih cepat. Dengan menggunakan teknologi digital, batas-batas teritorial sudah tidak menjadi penghalang lagi. Batas-batas wilayah walaupun fisiknya tetap ada, namun fungsinya sudah tidak dapat menghalangi lagi (borderless). Dalam kaitan ini tepat sekali apa yang dikatakan..... sebagai berikut: Because new technologyes become generallu avilable more quickly, tool has bocomr even more of a critical element in strategy. Nothing stay proprietary for long. And no rol played can master every thing. Thus operating globally means oportunity with panters and that in turn means a fuitther spread of technology. ${ }^{10}$ (Karena teknologi baru secara umum menyediakan percepatan lebih banyak, maka waktu menjadi demikian elemen yang paling kritis dalam menentukan strategi. Tidak ada tempat tinggal yang dapat disediakan untuk sepanjang zaman. Tidak ada seorang pemain yang dapat menadi guru bagi semua hal. Dengan demikian, pelaksanaan secara global berarti bekerjasama dengan patner dan hal itu sudah demikian pada tahap selanjutnya menyebarkan teknologi.

Salah satu program pemerintah untuk menjalankan amant Undang-Undang Dasar 1945 dalam rangka pemerataan pendidikan di Indonesia, menjadi sebuah kewajiban dalam penggunaan teknologi digital tidak terkecuali dalam aplikasi rapor

10 Kenichi Ohmae, The Borderless Wolrd, Power and Strategy in the Interlinked Economy (United State of America:Harper Business A Division pf HarperCollins Publishers, 1990), 5-6. 
digital ini. Oleh karena itu berbagai sarana prasarana dan infra struktur yang memungkinkan jaringan teknologi digital tersebut dapat ditransmisikan, seperi jaringan listrik, tiang pemancar, jaringan dan lainnya harus disiapkan. Juga di wilayah wilayah tertentu di Indonesia yang masih tertinggal dalam hal informasi berbasis IT termasuk daerah tertinggal maupun terpencil dan sulit dijangkau dengan alat transportasi dan lainnya.

Kelima, dewasa ini sumber belajar makin banyak dan varitif, baik dari segi materinya, jenis maupun bentuknya. Berbagai sumber belajar tersebut tidak mungkin lagi dapat dikuasai oleh seorang yang waktu, tenaga, dan lainnya terbatas. Sumber dan baha ajar saat ini sudah tersebar di berbagai media, seperi google, face book, you tobe, email, faximile, sms, vido call dan lain sebagainya. Perkembangan sumber belajar yang demikian itu telah merubah paradigma pembelajaran dari yang bersifat manual atau face to face menjadi bersifat digital dan terjadi secara interconnecting. Terkait dengan ini, menarik sekali apa yang dikatakan oleh Damain Ryan: Social media website come in a wide variety of "flavours", which are all broadly based around the premise of personal interaction; creating, exchanging and sharing contents, rating and discussing its relative merits as a community. The contents can be links to other website, new articles or blog post, photopraphs, audio, video, questions posed by other userts, anything, in fact, that can be distributed in digital form. ${ }^{11}$ (Media sosial website sudah sangat berkembang luas yang semakin luas jangkauannya guna mendukung interaksi antara manusia, menciptakan, tukar menukar and sharing pendapat, penyusunan dan diskusi tentang keunggiulan yang relatif pada sebuah masyarakat. Isi tersebut dapat berhubungan dengan website yang lain, artikel yang baru atau post blog, potografi, audio, video, pertanyaan yang diterapkan oleh pengguna, apapun dalam faktanya dapat dibagikan melalui bentuk digital.

Keenam, bahwa penggunaan teknologi digital dalam bentuk online misalnya sudah merambah ke dalam kegiatan sosial, ekonomi, politik, budaya dan lain sebagainya. Penggerakan masa dan pembentuk opini publik yang biasanya dilakukan dengan cara kampanye yang berhadapan langsung (face to face) dengan kelompok sasaran misalnya sudah dapat digantikan melalui blog, situs, web, face book, what's up dan sebagainya. Selanjutnya mempengaruhi orang untuk membeli sebuah jasa atau produk dalam bentuk makanan, minuman, pakaian, peralatan kosmetik,

\footnotetext{
11 Damian Ryan, Understanding Digital Marketing, Marketing Strategies for Enggaging the Digital Generation, (London, Philadelphia, New Delhi: Kogan Page, 2014), 156.
} 
peralatan teknologi, dan lainnya sudah dapat dilakukan melalui teknologi digital dalam bentuk on line. Seseorang yang membutuhkan jasa antara jemput dengan kendaraan roda dua, roda empat, kereta api, pesawat udara dan lainnya sudah dapat diorder melalui jaringan on line. Sikap dan budaya masyarakat yang sudah demikian familiar atau akrab dengan teknologi digital dalam bentuk on line adalah merupakan momentum yang tepat untuk dimanfaatan.

\section{Proses Pembelajaran Dan Penilaian Hasil}

Pembelajaran dapat didefinisikan dari berbagai sudut pandang, diantaranya adalah sudut pandang behavioristik. Berdasarkan teori ini pembelajaran sering dikatakan sebagai proses pengubah tingkahlaku siswa melalui pengoptimalan lingkungan sebagai sumber stimulus belajar. pembelajaran dalam teori ini ditafsirkan sebagai upaya pemahiran keterampilan melalui pembiasaan siswa secara bertahap dan terperinci dalam memberikan respons atas stimulus yang diterimanya yang diperkuat oleh tingkah laku yang patut dari pengajar,selanjutnya adalah pembelajaran dengan menggunakan pendekatan teori kognitif, dimana pembelajaran didefinisikan sebagai proses belajar yang dibangun oleh guru untuk mengembangkan kreativitas berpikir yang dapat meningkatkan kemampuan siswa dalam mengkonstruksi pengetahuan baru sebagai upaya meningkatkan penguasaan yang baik terhadap materi pelajaran, pembelajaran dengan pendekatan teori ini adalah sebagai upaya guru untuk memberikan stuimulus, bimbingan, pengarahan dan dorongan kepada siswa agar terjadi proses belajar. pembelajaran dengan pendeaktan teori ini merupakan proses pembentukan pengetahuan oleh siswa dan untuk siswa melalui optimalisasi kinerja kognitifnya.

Sedangkan dalam teori ketiga adalah teori pembelajaran interaksional, dalam teori ini didefinisikan bahwa pembelajaran merupakan proses interaksi peserta didik dengan pendidik dan sumber belajara pada suatu lingkungan belajar. pada proses ini menjembatani terjadinya proses interaksi antara guru, siswa maupun sumber belajar dan lingkungan belajar selama proses pembelajaran. ${ }^{12}$

Tema pembelajaran dalam konteks kurikulum 2013 diorientasikan untuk menghasilkan insan Indonesia yang produktif, kreatif, inovatif dan efektif melalui penguatan sikap(tahu apa)keterampilan (tahu bagaimana) dan pengetahuan (tahu apa) yang terintegrasi. Orientasi ini dilandasi oleh adanya kesadaran bahwa perkembangan kehidupan dan ilmu pengetahuan abad 21 , telah terjadi pergeseran

${ }^{12}$ Abidin, Desain Sistem Pembelajaran dalam Kontek Kurikulum 2013, 1-2. 
ciri dibanding dengan abad sebelumnya. Sejumlah ciri abad 21 merupakan abad informasi, komputasi, otomasi dan komunikasi. Ditinjau dari standar proses, sasaran pembelajaran dalam kurikulum 2013 mencakup pengembangan rana sikap, keterampilan dan pengetahuan yang dielaborasi untuk setiap satuan pendidikan. Oleh sebab itu proses pembelajaran yang semula terfokus pada eksplorasi, elaborasi dan konfirmasi difokuskan pada pembinaan sikap, keterampilan danpengetahuan melalui penerapan model pembelajaran yang tepat. Sejalan dengan kenyataan tersebut, proses belajar tidak hanya terjadi di ruang kelas, tetapi juga dilingkungan sekolah dan masyarakat. Oleh karenanya dalam pembelajaran ang mengimplementasikan kurikulum 2013, guru bukan satu-satunya sumber belajar. pada dimensi sikap, sikap tidak diajarkan secara verbal, tetapi melalui contoh, pembiasaan aktivitas sikap, sikap tidak diajarkan secara verbal, tetapi melalui contoh, pembiasaan aktivitas, dan teladan. Khusus pada jenjang sekolah dasar, pembelajaran dilakukan secara tematik integratif pada seluruh jenjang kelas. ${ }^{13}$

Proses pembelajaran tidak akan dapat dikatakan masimal atau sempurnah tanpa adanya penilaian, oleh karena itu salah satu tugas guru yang tidak dapat ditinggalkan setelah melakukan proses pembelajaran dan penugasan adalah penilaian.

Permendikbud Nomor 66 Tahun 2013 tentang Standar Penilaian Pendidikan disebutkan bahwa penilaian hasil belajar peserta didik pada jenjang pendidikan dasar dan menengah didasarkan pada prinsip-prinsip sebagai berikut:

a. Objektif, berarti penilaian berbasis pada standardan tidak dipengaruhi faktor subjektivitas penilai.

b. Terpadu, berarti penilaian oleh pendidik dilakukan secara terencana, menyatu dengan kegiatan pembelajaran, dan berkesinambungan.

c. Ekonomis, berarti penilaian yang efisien dan efektif dalam perencanaan, pelaksanaan, dan pelaporannya.

d. Transparan, berarti prosedur penilaian, kriteria penilaian, dan dasar pengambilan keputusan dapat diakses oleh semua pihak.

e. Akuntabel, berarti penilaian dapat dipertanggungjawabkan kepada pihak internal sekolah maupun eksternal untuk aspek teknik, prosedur, dan hasilnya.

f. Edukatif, berarti mendidik dan memotivasi peserta didik dan guru.

\footnotetext{
${ }^{13}$ Abidin, Desain Sistem Pembelajaran dalam Kontek Kurikulum 2013, 20.
} 
Jika dibandingkan dengan prinsip-prinsip penilaian hasil belajar di atas dengan prinsip-prinsip umum yang ditetapkan oleh Badan Standar Nasional Pendidikan, maka nampak prinsip-prinsip di atas lebih ringkas dari pada yang ditetapkan oleh BNSP. ${ }^{14} \mathbf{i}$ penilaian yang harus dilakukan adalah penilaian menyeluruh baik proses maupun hasil belajar siswa secara valid dan reliabel. Penilaian kurikulum 2013 akan berhasil jika penilaian yang dikembangkan di sekolah bukan hanya penilaian konvensional (paper dan pencil test) melainkan juga penilaian performa, penilaian proses, penilaian sikap, penilaian diri sendiri, dan juga penilaian portofolio. Penerapan penilaian outentik ini diyakini akan mampu meningkatkan kompetensi kritis kreatif siswa sebab penilaian outentik bukanlah penilaian yang menuntut jawaban tunggal sebagaimana penilaian konvensional yang selama ini digunakan yang lebih banyak menghendaki jawaban tunggal/kebenaran tunggal. ${ }^{15}$

Dalan kurikulum 2013 penilaian dilakukan dengan menggunakan pendekatan penilaian autentik seperti yang terdapat dalam bab $V$ salinan lampiran Peraturan Menteri Pendidikan dan Kebudayaan Republik Indonesia nomor 65 tahun 2013 tentang Standar Proses Pendidikan Dasar dan Menengah dijelaskan bahwa:

Penilaian proses pembelajaran menggunakan pendekatan penilaian autentik (authentic assesment)yang menilai kesiapan siswa, proses, dan hasil belajar secara utuh. keterpaduan penilaian ketiga komponen tersebut akan menggambarkan kapasitas, gaya, dan perolehan belajar siswa atau bahkan mampu menghasilkan dampak instruksional (instructional effect) dan dampak pengiring (nurturant effect) dari pembelajaran. Hasil penilaian autentik dapat digunakan oleh guru untuk merencanakan program perbaikan (remedial), pengayaan (enrichment), atau pelayanan konseling. selain itu, hasil penilaian autentik dapat digunakansebagai bahan untuk memperbaiki proses pembelajaran sesuai dengan standar penilaian pendidikan. evaluasi proses pembelajaran dilakukan saat proses pembelajaran dengan menggunakan alat: angket, observasi, catatan anekdot, dan refleksi. ${ }^{16}$

Istilah autentik merupakan sinonim dari asli, nyata, valid, atau variable.

Jadi penilaian autentik adalah proses pengumpulan informasi tentang perkembangan dan pencapaian pembelajaran yang dilakukan oleh peserta didik melalui berbagai teknik yang mampu mengungkapkan, membuktikan atau menunjukkan secara tepat bahwa tujuan pembelajaran telah benar-benar dikuasai

\footnotetext{
14 Prinsip-prinsip umum penilaian hasil belajar menurut BSNP adalah sebagai berikut: mendidik; terbuka atau transparan; menyeluruh; terpadu dengan pembelajaran; objektif; sistematis; berkesinambungan; adil; dan pelaksanaannya menggunakan acuan kriteria.

15 Yunus Abidin, Desain Sistem Pembelajaran dalam Kontek Kurikulum 2013 (Bandung: PT. Refika Aditama, 2013), 35.

16 Peraturan Menteri Pendidikan dan Kebudayaan Republik Indonesia nomor 65 tahun 2013 tentang Standar Proses Pendidikan Dasar dan Menengah.
} 
dan dicapai. Berdasarkan lampiran Permendikbud Nomor 66 Tahun 2013 tantang Standar Penilaian yang dilakukan secara komperhensif untuk menilai, mulai dari proses hingga keluar (output) pembelajaran. Penilaian autentik mencakup ranah sikap, keterampilan, dan pengetahuan. ${ }^{17}$

Sedangkan dalam Peraturan Menteri Pendidikan Dan Kebudayaan Republik Indonesia Nomor 66 tahun 2013 dijelaskan bahwa:

Penilaian pendidikan sebagai proses pengumpulan dan pengolahan informasi untuk mengukur pencapaian hasil belajar peserta didik mencakup: penilaian autentik, penilaian diri, penilaian berbasis portofolio, ulangan, ulangan harian, ulangan tengah semester, ulangan akhir semester, ujian tingkat kompetensi, ujian mutu tingkat kompetensi, ujian nasional, dan ujian sekolah/madrasah, Penilaian autentik dalam kurikulum 2013 merupakan penilaian yang dilakukan secara komprehensif untuk menilai mulai dari masukan (input), proses,dan keluaran (output) pembelajaran. ${ }^{18}$

Penilaian atau asesmen hasil belajar oleh pendidik dimaksudkan untuk mengukur kompetensi atau kemampuan tertentu terhadap kegiatan yang telah dilaksanakan dalam kegiatan pembelajaran, sedangkan penilaian untuk mengetahui sikap digunakan teknik nontes. Asesmen autentik adalah pengukuran yang bermakna secara signifikan atas hasil belajar peserta didik untuk ranah sikap, keterampilan, dan pengetahuan. Istilah asesmen merupakan sinonim dari penilaian, pengukuran, pengujian atau evaluasi. Istilah autentik merupakan sinonim dari asli, nyata, valid, atau reliable. Secara konseptual, asesmen autentik lebih bermakna secara signifikan dibandingkan dengan tes pilihan ganda terstandar sekalipun. Ketika menerapkan asesmen autentik untuk mengetahui hasil dan prestasi belajar peserta didik, guru menerapkan kriteria yang berkaitan dengan konstruksi pengetahuan, aktivitas mengamati dan mencoba, dan nilai prestasi luar sekolah. ${ }^{19}$

Asesmen autentik memiliki relevansi kuat terhadap pendekatan ilmiah dalam pembelajaran sesuai dengan tuntutan Kurikulum 2013, karena penilaian/asesmen semacam ini mampu menggambarkan peningkatan hasil belajar peserta didik, baik dalam rangka mengobservasi, menalar, mencoba, membangun jejaring, dan lain-lain. Asesmen autentik cenderung fokus pada tugas-tugas kompleks atau kontekstual, memungkinkan peserta didik untuk menunjukkan kompetensi mereka dalam

${ }^{17}$ Munardi dan Selly Rahmawati, Penilaian dalam Kurikulum 2013: Membantu Guru dan Calon Guru Mengetahui Langkah-langkah Penilaian Pembelajaran, (Jogjakarta: Andi, 2013), 27

18 Peraturan Menteri Pendidikan Dan Kebudayaan Republik Indonesia Nomor 66 Tahun 2013 Tentang Standar Penilaian Pendidikan, 2

19 Hosnan, Pendekatan Saintifik dan Konstektual dalam Pembelajaran Abad 21, Kunci Sukses Implementasi Kurikulum 2013, (Bogor: Ghalia Indonesia, 2014), 287. 
pengaturan yang lebih autentik. Karenanya, asesmen autentik sangat relevan dengan pendekatan tematik terpadu dalam pembelajaran, khususnya jenjang sekolah dasar atau untuk mata pelajaran yang sesuai. ${ }^{20}$

Penilaian harus memandu strategi pembelajaran dan strategi pembelajaran senantiasa berorientasi pada penilaian. Dalam konsep ini dapat dijelaskan bahwa ketika pembelajaran membaca misalnya, kompetensi yang harus dicapai siswa adalah membuat inti sari bacaan. Berdasarkan tujuan tersebut, strategi pembelajaran yang dipilih harus berisi seperangkat aktivitas yang langsung membina kemampuan siswa, menyusun tujuan tersebut, strategi pembelajaran yang dipilih haruslah berisi seperangkat aktivitas yang secara langsung membina kemampuan siswa membuat inti sari bacaan. Aktivitas yang dimaksud adalah menggali skema siswa, menyusun tujuan membaca, menemukan ide pokok bacaan, menyusun peta konsep isi bacaan dan mengembangkan inti sari bacaan. Keseluruhan aktivitas ini dikenal dengan istilah strategi membaca skema kritis. Berdasarkan contoh ini diketahui bahwa jenis penilaian yang digunakan yakni penilaian kemampuan membuat intisasri bacaan memadu aktivitas pembelajaran dan aktivitas pembelajaran senantiasa berorientasi pada pembentukan kemampuan yang akan dinilai. Jika pembelajaran senantiasa berorientasi pada pembentukan kemampuan yang akan dinilai. Jika pembelajaran hanya dilakukan secara tradisional misalnya membaca dan menjawab pertanyaan, diyakini siswa akan gagal dalam membuat intisari bacaan. ${ }^{21}$

Penilaian hasil belajar oleh pendidik yang dilakukan secara berkesinambungan tidak lain memiliki tujuan yaitu memantau proses dan kemajuan belajar para peserta didik agar dapat meningkatkan efektivitas proses pembelajaran.

\section{Pengertian dan Pentingnya Aplikasi Rapor Digital (ARD)}

Komponen hasil belajar yang tidak dapat dilepaskan adalah Penilaian hasil belajar. Keharusan melaksanakan penilaian hasil belajar ditegaskan dalam Peraturan Menteri Pendidikan dan Budaya Nomor 66 Tahun 2013 tentang Standar Penilaian Pendidikan bahwa standar penilaian bertujuan untuk menjamin: (1) Perencanaan peserta didik sesuai dengan kompetensi yang dicapai berdasarkan prinsip-prinsip penilaian, (2) Pelaksanaan penilaian peserta didik secara profesional, terbuka, edukatif, efektif, efisien, dan sesuai dengan

20 Ibid., 389-390.

21 Abidin, Desain Sistem Pembelajaran dalam Kontek Kurikulum 2013, 97. 
konteks sosial budaya, serta (3) Pelaporan hasil penilaian peserta didik secara objektif, akuntebel dan informatif. ${ }^{22}$

Sedangkan untuk memenuhi standar penilaian harus memperhatikan prinsip-prinsip penilaian. Seperti yang dijelaskan oleh Widoyoko, prinsip-prinsip penilaian mencakup: sahih atau valid, objektif, adil, terpadu, terbuka, menyeluruh dan berkesinambungan, sistematis, ekonomis, akuntabel, dan edukatif. ${ }^{23}$

Nilai adalah konsep-konsep umum tentang sesuatu yang dianggap baik, patut, layak, pantas yang keberadaannya dicita citakan, diinginkan, dihayati, dan dilaksanakan dalam kehidupan sehari hari dan menjadi tujuan kehidupan bersama di dalam kelompok masyarakat tersebut, mulai dari unit kesatuan sosial terkecil hingga suku, bangsa, dan masyarakat internasional. Nilai adalah salah satu tolak ukur keberhasilan siswa menempuh pendidikan disekolah. ${ }^{24}$

Aplikasi pengolah nilai adalah aplikasi yang dapat membantu para pengajar atau bagian akademik atau petugas yang bekerja merekap nilai secara detail dari Ujian (PTS, PAS, praktikum), nilai per tugas (quiz, praktek, Pekerjaan Rumah) dan mencatat total kehadiran siswa. Aplikasi ini diperuntukkan untuk institusi pendidikan dalam manajemen nilai siswa, dengan fasilitas mencetak transkrip persemester, lembar kehadiran, Nilai Tengah Semester, Nilai Akhir Semester, info tugas siswa dan rekap info nilai tugas siswa ${ }^{25}$

Aplikasi Pendidikan dalam program penilaian dan analisis ini kiranya dapat meringankan beban guru dalam proses penilaian, baik penilaian ulangan harian, tugas-tugas, portofolio, perbaikan, pengayaan, dan lain-lain. Jika program penilaian hasil belajar siswa ini dijalankan secara teratur, guru tidak akan lagi kebingungan menilai siswa secara menyeluruh dan objektif sehingga guru tidak lagi main tembak dalam menilai siswa sehingga didapat perangkingan siswa dengan kondisi yang sebenarnya. ${ }^{26}$

22 Permendikbud nomor 66 tahun 2013.

${ }^{23}$ Eko Putro Widoyoko, Penilaian Hasil Pembelajaran di Sekolah (Yogyakarta: Pustaka Belajar, 2014$), 17$.

24 Jamers A. O’Brien dan George M. Marakas, (2014). Konsep Dasar: Komponen Sistem Informasi, "Sistem Informasi Manajemen", Edisi 9 - buku 1,Mc Graw Hill Education, Salemba Empat, 2014,27

${ }^{25}$ Eko Travada, Aplikasi Pengolahan Nilai Dosen (offline version), dalam https: //ekotravada1210.wordpress.com/2011/03/30/aplikasi-pengolahan-nilai-akademik-perguruan- tinggi/, diakses tanggal 10 September 2020,

26 Deni Ranoptri, Aplikasi Pengolah Nilai Hasil Belajar Siswa Dilengkapi dengan Analisis, dalam https://www.datasekolah.co.id/2015/08/aplikasi-pengolah -nilai-hasil-belajar. html?m=1, diakses tanggal tanggal 10 September 2020. 
Oleh karena itu maka dalam kurikulum 2013 Standar pemanfaatan penilaian hasil belajar pada Kurikulum 2013 diantaranya adalah: ${ }^{27}$ a) Melaporkan hasil penilaian untuk semua mata pelajaran pada setiap akhir semester kepada orang tua/wali peserta didik dalam bentuk raport. b) Menyusun deskripsi yang menjelaskan makna nilai akhir untuk setiap mata pelajaran yang diberikan kepada setiap peserta didik. c) Melaporkan kelulusan peserta didik dari satuan pendidikan lengkap dengan nilai yang dicapai kepada orang tua/walinya. d) Melaporkan pencapaian hasil belajar tingkat satuan pendidikan setiap tahun kepada Dinas Pendidikan Kabupaten/Kota. e) Menganalisis ketercapaian standar kompetensi pada kurikulum berdasarkan hasil ujian sekolah dan melakukan tindak lanjut untuk meningkatkan mutu kompetensi peserta didik.

Aplikasi rapor digital ini memiliki beberapa menu yang harus diisi oleh operator madrasah. Kedua menu tersebut adalah menu beranda dimana didalamnya terdapat menu guru, siswa serta menu ekstrakurikuler dan menu untuk belajar. menu selanjutnya adalah menu konfigurasi memuat menu madrasah, mata pelajaran, muatan lokal, ekstrakurikuler, guru, siswa dan golongan belajar.

Aplikasi ini membantu operator dalam print out hasil belajara para peserta didik, disini yang tercantum adanya kuantitas nilai juga deskripsi nilai pengetahuan dan pemahaman siswa, berbagai kemampuan serta keterampilan siswa dideskripsikan secara detail setiap mata pelajaran. Dari deskripsi yang ada didalam rapor ini orang tua akan mengetahui seberapa jauh hasil belajara anaknya selama satu semester.

Sebelum di save pengisian data profil siswa pada aplikasi ARD ini harus diisi penuh, karena kalau hanya diisi sementara maka saving file akan menjadi error, begitu juga dengan input catatan siswa selama satu semester yang harus diisi secara maksimal supaya mampu di print out dalam bentuk Soft file pdf.

Selain itu adapula kelemahan dari aplikasi ARD ini mulai dari kewajiban terhubung dengan server utama, teknis input yang serba menggunakan klik (yang idealnya pake enter/tab seperti halnya pada Ms. Excel), input deskripsi yang serba manual, serta input data siswa yang agak ribut, ditambah lagi patching raport yang berbeda-beda pada setiap komponen.

ARD merupakan aplikasi pendataan dan administrasi lembaga madrasah secara online. Aplikasi ini dikhususkan dalam digitalisasi dan standardisasi rapor sehingga data rapor peserta didik madrasah tersimpan pada database Kementrian

${ }^{27}$ Kunandar, Penilaian Autentik; Penilaian Hasil Belajar Peserta Didik Berdasarkan Kurikulum 2013 (Jakarta: PT Rajagrafindo Persada, 2013), 77. 
Agama Republik Indonesia. Apabila data yang ada diperlukan sewaktu-waktu dapat secara cepat, tepat dan akurat untuk diakses. Untuk proses verifikasi datapun sangat mudah, hal ini tidak lain adalah bahwa data dapat diakses secara online. ARD merupakan aplikasi rapor yang pengoperasionalannya dapat dilakukan secara online berbasis Web maupun Android, sehingga guru dapat mengelola penilaian hasil belajar kapanpun dan dari manapun. ${ }^{28}$

Selain kemudahan mendapatkan data secara akurat ARD dapat pula di operasikan secara offline. Sungguh sesuatu yang sangat meringankan dan mempermudah siapapun untuk mendapatkan data akurat terkait nilai peserta didik disuatu lembaga.Aplikasi offline ini dapat dipergunakan, hingga nanti ketika sudah dapat login ke layanan ARD tinggal menguploadnya (unggah). Kelebihannya, jika ARD secara online mengalami kendala, maka dapat beralih ke ARD Offline .

Sejarah perjalanan perkembangan Aplikasi Rapor Digital (ARD) sangat panjang. Dalam perkem -bangannya, aplikasi rapor yang berbasis online mulai diterapkan di Indonesia sejak tahun 2013. Nama aplikasi rapor yang berbasis online tersebut adalah Rapor Online, yang digagas oleh Kementrian Pendidikan dan Kebudayaan. Program ini diperuntukkan untuk sekolah-sekolah yang berada di bawah naungan Kementrian Pendidikan dan Kebudayaan Republik Indonesia. Sedangkan pada madrasah ada yang namanya ARD Madrasah, yang merupakan aplikasi rapor yang berbasis online yang digagas oleh Kementrian Agama yang baru diluncurkan pada Oktober 2018. ${ }^{29}$

ARD bertujuan agar pengelolaan penilaian hasil belajar dapat dilakukan secara cepat, tepat, akurat, efektif, dan efisien. ${ }^{30}$ Dengan kemampuan para SDM madrasah yang maksimal dalam mengaplikasikan rapor digital ini maka setiap data yang ada akan dapat diakses dan disimpan dengan baik di aplikasi yang sudah dikerjakan oleh masing-masing wali kelas dan tentunya lembaga dan kementrian agama dapat mengakses nilai para peserta didik di setiap lembaga dengan berbagai kemudahan tanpa ribet mencari data secara manual.

\footnotetext{
28 Keputusan Direktur Jenderal Pendidikan Islam nomor 6003 tahun 2018 tentang Juknis Bimtek ARD Madrasah, 1.

29 Kemdikbud, Panduan Penggunaan erapor 2017. Online. http//psma.kemdikbud.go.id/.diakses 22 Oktober 2020.

30 Keputusan Direktur Jenderal Pendidikan Islam nomor 6003 tahun 2018 tentang Juknis Bimtek ARD Madrasah, 1
} 


\section{Implementasi Program}

Adapun maksud dan tujuan pendampingan ini adalah agar para guru, wali kelas mampu mengoperasionalkan ARD secara mandiri dan baik. Kegiatan sosialisasi ini penting dilakukan bermanfaat dapat menciptakan komunikasi serta dialogsi yang interaktif dengan para kondisi dampingan (guru). Tahapan yang dilakukan diantaranya adalah : (1) menghadirkan para guru dilingkungan Yayasan Miftahul Jinan sebagai sasaran utama kegiatan pendampinga (2) menghadrikan seluruh unsur elemen seperti stake holders, kepala madrasah untuk meminta izin dan dukungan dalam pelaksanaan program pendampinga dan indetifikasi potensi madrasah (3) melakukan kunjungan dan diskusi kelompok sasaran utama pendampingan agar turut berpartisipasi aktif dalam program pendampingan.

Kegiatan program dilakukan pertama kali dengan memberikan materi tentang pemahaman ARD kepada para dampingan. Metode dan bentuk kegiatan pengabdian kepada para guru ini adalah pelatihan, dengan teknik: ceramah dan diskusi tentang pentingnya ARD yang divariasikan dengan diskusi dan tanya jawab, demonstrasi dan penugasan. Jenis kegiatan yang dilakukan adalah pelatihan dalam rangka meningkatkan pengetahuan, pemahaman dan keterampilan bagi wali kelas dan guru tentang pembuatan Aplikasi Raport Digital (ARD). Objek sasaran dari kegiatan pendampingan dan pelatihan ini ialah wali kelas, guru, operator madrasah di Madrasah ibtidaiyah Miftahul Jinan sebanyak 15 orang dan 6 orang dari RA Miftahul Jinan. Untuk mengetahui keberhasilan pelatihan ini digunakan tes, tes diberikan sebelum pelaksanaan pelatihan (tes awal) dan setelah selesai kegiatan (tes akhir). Tes berjumlah 10 soal berbentuk pilihan ganda. Hasil tes akan dihitung, diskor, dan direrata. Kegiatan ini dinyatakan berhasil bila jumlah rata-rata tes akhir lebih besar daripada tes awal. Peningkatan yang terjadi dari pengetahuan awal ke pengetahuan akhir dihitung dengan rumus $\mathrm{g}$ factor $(\mathrm{N}$ Gain) dengan menggunakan rumus Hake (1999):

$\mathrm{N}$ Gain $=\underline{\text { Skor post }- \text { Skor pre }}$

Skor maks - Skor pre

Keterangan:

Spost : Skor Tes Akhir

Spre : Skor Tes Awal

Hasil dan Pembahasan Kegiatan pelatihan ini dilaksanakan dalam waktu empat bulan terhitung dari mulai disusunnya proposal PARD. Sebelum memberikan pelatihan pembuatan Aplikasi Rapor Digital terlebih dahulu diadakan tes awal untuk mengetahui 
tingkat pemahaman guru-guru mengenai ARD. Kemudian kegiatan pertama pelaksanaan tatap muka dengan penyampaian materi tentang ARD, kegiatan kedua adalah praktik pelatihan ARD. Kegiatan ketiga berupa lanjutan pembimbingan pembuatan ARD pada tanggal 08 September 2020. Kegiatan ini diikuti oleh Wali kelas dan operator dilingkungan Yayasan Miftahul Jinan yang meliputi MI dan RA Miftahul Jinan dengan jumlah peserta 15 orang dan RA Miftahul Jinan sebanyak 5 orang, tetapi yang hadir 16 orang sedangkan 4 orang lainnya berhalangan hadir. Dari hasil tes awal terlihat bahwa $70 \%$ wali kelas, guru belum terlalu memahami mengenai ARD, namun ada pula peserta yang terlihat sudah cukup baik pemahamannya mengenai ARD. Selanjutnya kegiatan PARD dilanjutkan dengan penyampaian materi oleh P. Samsul, S.Pd, sekaligus praktik pembuatan ARD yang didampingi oleh P. Bejo, S.Pd, yang merupakan salah satu tim dalam ARD tersebut.

Hal pertama yang diajarkan oleh pendamping pelatihan ARD ini adalah sebagai berikut:

\section{Membuat Akun,}

Setiap peserta dapat login ke aplikasi ARD Madrasah dengan akunnya masingmasing. Guru, wali kelas dapat melakukan pengisian nilai hasil belajar siswa sesuai dengan mata pelajaran serta rombongan belajaran yang diampu.

Agar dapat memengakses akun tersebut, maka dapat melakukan hal-hal di bawah ini:

a. Pilih username : sesuai yang telah diisikan oleh pendamping saat entri data guru dalam kolom "NIP"

b. Masukkan password : sesuai yang diisikan oleh pendamping saat entri data guru di kolom "kata sandi"

\section{Konfigurasi Bobot dan Isi KKM}

Langah selanjutnya setelah berhasil login dan masuk ke ARD Madrasah akun guru, lakukan konfigurasi bobot dan KKM (Kriteria Ketuntasan Minimal) untuk setiap mata pelajaran per kelas sebagaimana yang diampukan kepada yang bersangkutan. Cara melakukan konfigurasi bobot dan KKM adalah:

a. Klik menu "Konfigurasi"

b. Klik submenu "Bobot dan KKM"

c. Pada layar bagian kanan, klik tombol "Ubah" di akhir mata pelajaran dan kelas yang tertera 


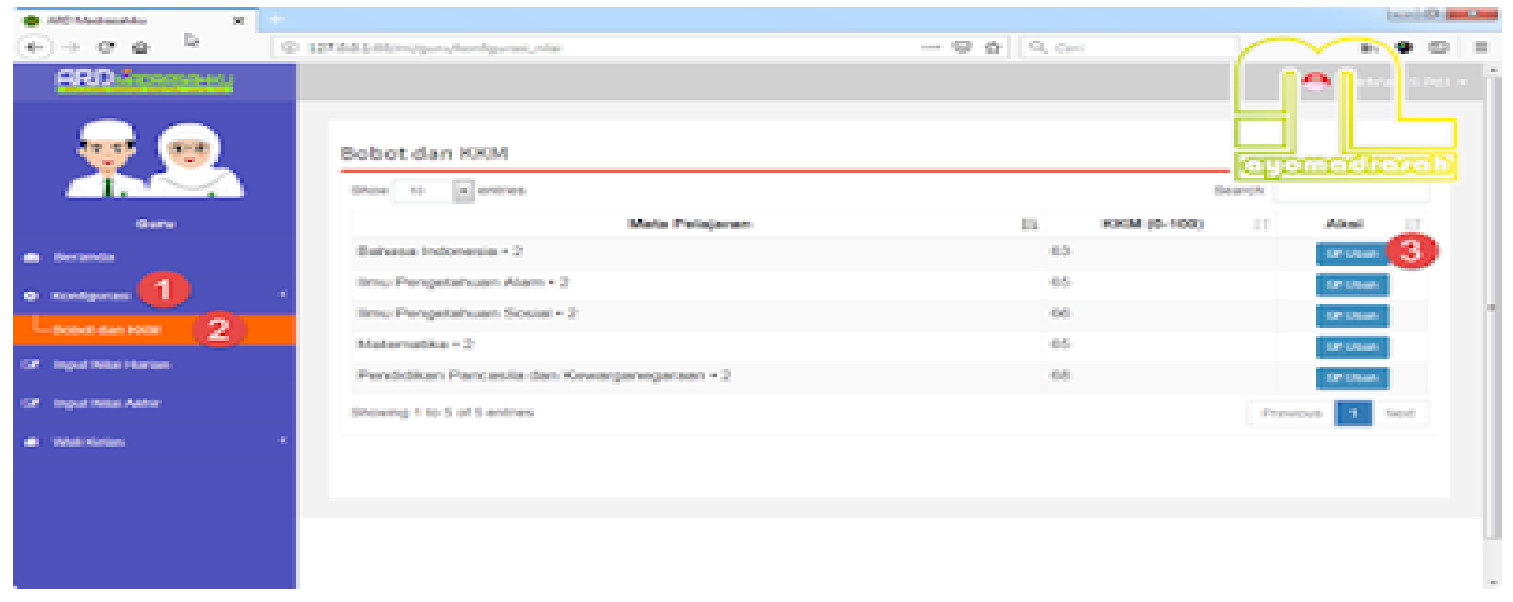

d. Terbuka halaman baru

e. Isikan bobot penilaian pengetahuan untuk RPH (Rata-rata Penilaian Harian) dan PAS. Total keduanya harus 100 . Bobot ini sesuai kesepakatan antara madrasah dengan guru. Contoh: Bobot RPH 60, Bobot PAS 40. Lihat poin 4 pada gambar.

f. Isikan bobot penilaian keterampilan yang meliputi Praktik, Portofolio, dan Projek. Total ketiganya harus 100. Lihat poin 5 pada gambar

g. Isikan KKM dengan rentang antara 0-100. Lihat poin 6 pada gambar

h. Predikat akan terisi otomatis

i. Klik "Simpan"

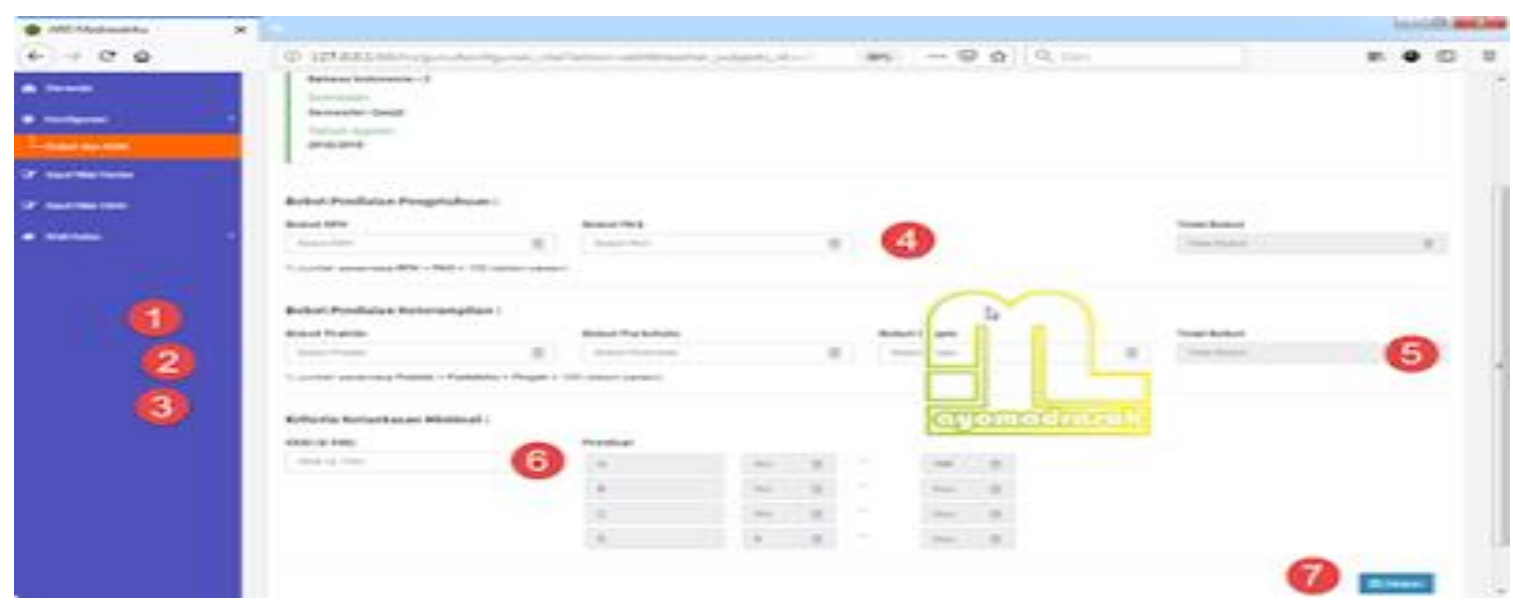

j. Muncul jendela notifikasi "Data Berhasil diubah", klik "Tutup"

k. Kembali ke halaman Bobot dan KKM dengan kemunculan nilai KKM yang telah diisikan tadi.

Langkah selanjutnya yang dapat dilakukan oleh guru, wali kelas adalah dengan mengulang kembali langkah-langkah seperti sebelumnya sehingga semua pelajaran yang diampu atau dimasukkan terisi dengan KKM nya sekaligus. 
Apabila ada tambahan mata pelajaran yang belum tertera dalam daftar maka bisa ditambahkan, selanjutnjutnya akan muncul daftar nama pelajaran tersebut.

\section{Input Nilai Harian}

Agar dapat mengisi nilai harian setiap peserta didik dalam setiap mata pelajaran yang ada dapat dilakukan dengan cara-cara sebagai berikut:

a. Klik menu Input Nilai Harian (no. 1)

b. Pada layar sebelah kanan, klik segitiga di ujung kanan kolom Mata Pelajaran hingga muncul daftar mata pelajaran yang diampu (no. 2)

c. Klik salah satu mata pelajaran yang muncul (no. 3)

d. Klik "Cari" (no. 4)

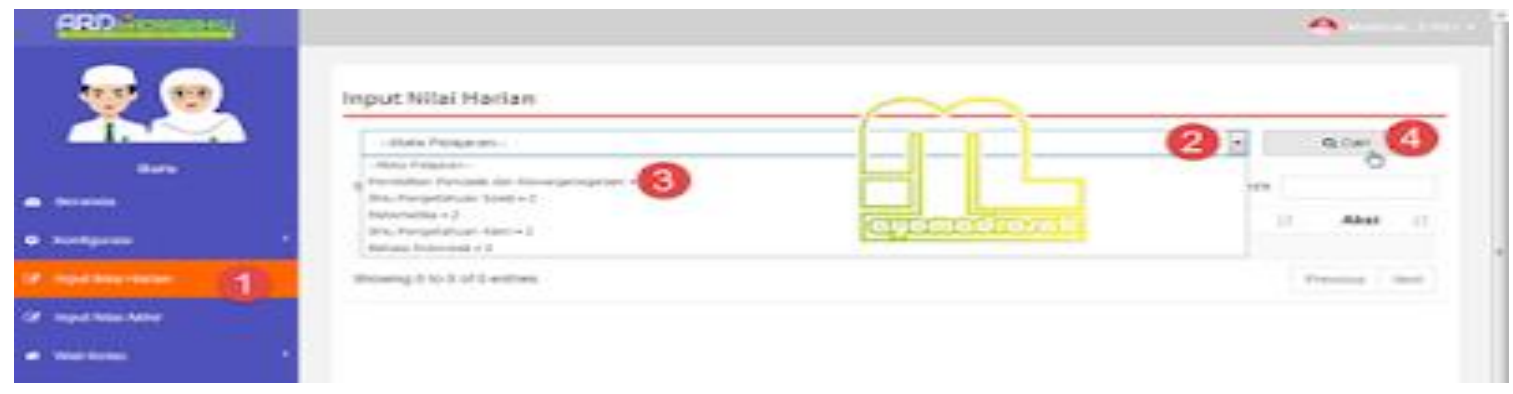

e. Muncul daftar rombel yang diampu untuk mata pelajaran tersebut

f. Klik tombol "Input Nilai" (no. 5)

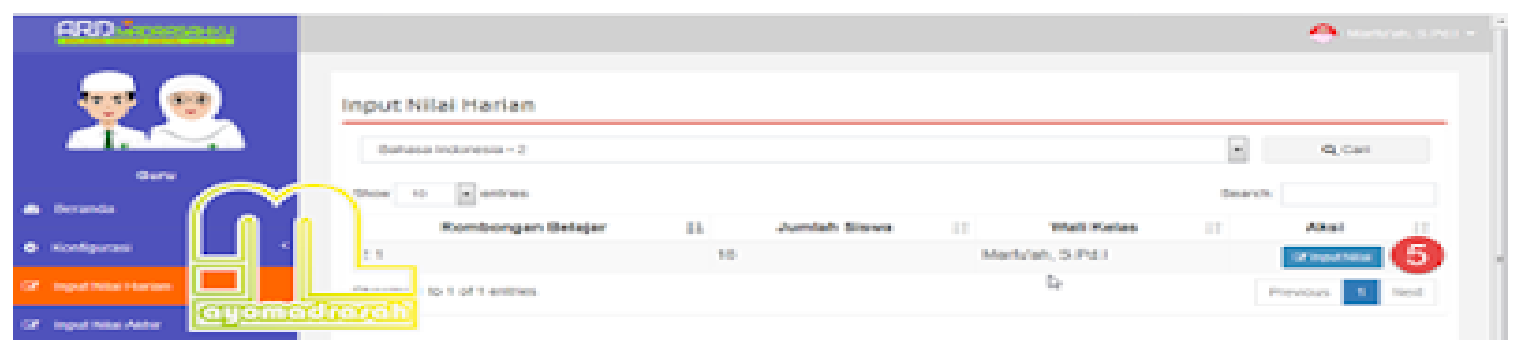

g. Muncul daftar siswa dalam satu rombel lengkap dengan kolom $\mathrm{PH} 1, \mathrm{PH} 2, \ldots$, PH10, dan RPH

h. Isikan kolom nilai pada bagian PH sesuai nilai yang diraih siswa tersebut

i. Jika terdapat nilai yang kurang dari KKM, silakan isi kolom remidi dengan nilai yang diperoleh

j. Kolom RPH terisi otomatis

k. Jumlah PH yang diisi sesuai kebutuhan

l. Isikan untuk semua siswa 


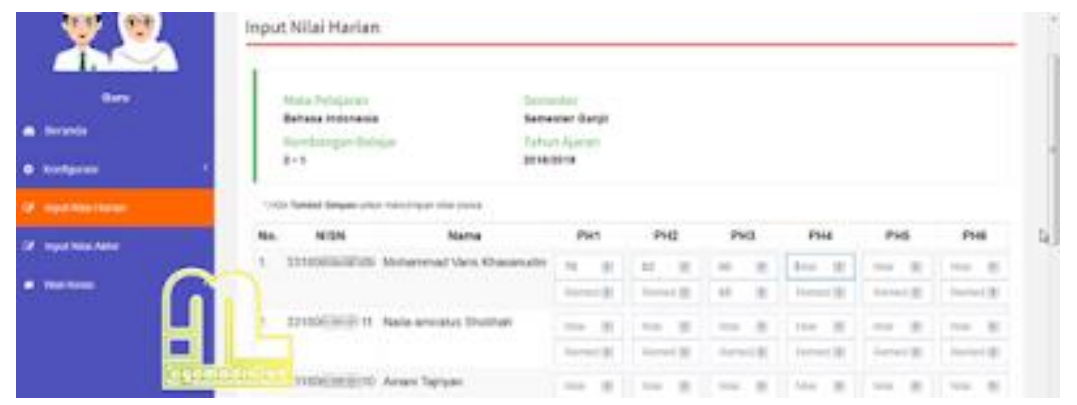

m. Jika sudah klik tombol "simpan" yang ada di pojok kanan bawah

n. Nilai ini dapat diisi seluruhnya baru disimpan atau dapat juga diisi sebagian lalu disimpan dan diedit lagi pada lain kesempatan.

o. Setelah disimpan, muncul jendela pesan, klik "Tutup"

p. Untuk mengisi nilai harian mapel atau rombel lainnya, klik menu "Input Nilai Harian"

\section{Input Nilai PAS}

Nilai belum seluruhnya sempurnah dimasukkan karena masih ada nilai PAS (Penilaian Akhir Aemester) yang harus diinput. Untuk input nilai PAS maka akan secara otomatis dihitung dangan nilai RPH sehingga akan menghasilkan NA (Nilai Akhir), dan penghitungan ini sesuai dengan Bobot Nilai pada langkah sebelumnya. Namun jika (Konfigurasi Bobot dan KKM) belum dilakukan maka nilai tidak akan dapat dihitung secara otomatis menjadi nilai akhir.

Sedangkan untuk wali kelas dapat melakukan dengan cara masuk ke akun wali kelas agar dapat mencetak rapor langkah tersebut dapat dilakukan dengan :

a. Klik menu "Wali Kelas" lalu klik siswa.

b. Selanjutnya silakan klik menu catatan siswa kemudian masukkan catatan pada siswa yang bersangkutan.

c. Langkah selanjutnya jika semua siswa sudah diberi catatan langkah selanjutnya adalah dengan cetak rapor dan cetak leger.

d. Proses input nilai dan cetak rapor dan leger telah selesai.

Selama proses praktik, peserta sangat antusias karena merasa pembuatan ARD tidak terlalu sulit. Saat proses praktik ARD ini tidak jarang para peserta masih ada yang kesulitan karena tidak semuanya paham IT secara paripurna, karena memang ada guru-a yang penuh dengan kesabaran maka kegiatan pendampingan Aplikasi Rapor Digital ini dapat tuntas tersampaikan, selanjutnya dilakukan post tes untuk mengukur kemajuan guru dan wali kelas tentang ARD. 
Kemudian produk yang dihasilkan oleh para wali kelas dikoreksi dan diverivikasi oleh tim Pelatihan Pendampingan Aplikasi Rapor Digital (PARD). Hasilnya Dapat dikatakan bahwa para wali kelas di MI Miftahul Jinan telah mampu mengaplikasikan ilmu yang diberikan narasumber terkait langkah-langkah pembuatan Aplikasi Rapor Digital (ARD). Serta hasil akhirnya para wali kelas, guru dan operator telah mampu menghasilkan rapor digital sesuai harapan lembaga.

Adapun perbandingan tes awal dan tes akhir peserta pelatihan disajikan ke dalam tabel berikut:

\begin{tabular}{|l|l|l|l|}
\hline No & Nama & Nilai Pre Test & Post Tes \\
\hline 1 & M. Anam & 70 & 80 \\
\hline 2 & Aprilia & 60 & 70 \\
\hline 3 & Diniatul & 70 & 80 \\
\hline 4 & Sri Utami & 60 & 70 \\
\hline 5 & Khusnul & 60 & 70 \\
\hline 6 & Khoiroh & 60 & 70 \\
\hline 7 & Else & 60 & 80 \\
\hline 8 & Hanifah & 60 & 70 \\
\hline 9 & Maria & 60 & 70 \\
\hline 10 & Layyinah & 50 & 70 \\
\hline 11 & Putri Rizkiyah & 70 & 80 \\
\hline 12 & Novi Lailus & 60 & 70 \\
\hline 13 & Faizzatul & 60 & 70 \\
\hline 14 & Mustainah & 60 & 70 \\
\hline 15 & Fitria & 50 & 70 \\
\hline 16 & Hanim & 60 & 70 \\
\hline Total & & 60.6 & 72.5 \\
\hline & Tabel & & \\
\hline
\end{tabular}

Tabel di atas menunjukkan bahwa rata-rata skor pre test sebesar 60,6, dan nilai post test menunjukkan bahwa rata-ratanya sebesar 72,5. Hal ini dapat diambil sebuah kesimpulan bahwa bahwa terdapat peningkatan sebesar 11,9 dan di dapatkan N-Gain sebesar 0,3 dengan kategori sedang. Berdasarkan hasil tabel di atas menunjukkan bahwa mayoritas peserta pelatihan mengalami peningkatan dalam hasil tesnya. Kegiatan pelatihan ini tentunya menunjukkan peningkatan terkait pengetahuan dan pemahaman para peserta pelatihan ARD. 
Suatu program dapat dikatakan berhasil dengan dikur dari kegitan program dan evaluasi. Monitoring dan evaluasi sangat penting dilakukan dalam menentukan keberhasilan program yang mana nantinya dapat diketahui sejauh mana efektivitas dan efesensi program pemberdayaan dilakukan dan dampak bagi masyarakat. ${ }^{31}$

Aspek yang menjadi imonitoring dan evaluasi dalam program ini adalah pada komponen pencapaian dan dampak proses pemberdayaan belum dilakukan. Evaluasi pada komponen input dari pelaksanaan program pendampingan, dilakukan untuk melihat kesiapan dari tim fasilitator berupa partisipasi aktif dalam pelaksaan program. Evaluasi kesiapan berupa kemampuan memotivasi diri baik bagi diri sendiri maupun kondisi dampingan. Kemampuan para pengelola program pendampingan dan kesiapan infrastuksur dan sistem adamistrasi pendukung kegiatan pendampingan.

Pada aspek sosialisasi dikatakan berhasil karena dihadiri seluruh elemen sekolah baik dari stake holders, kepala sekolah, wali kelas, operator.dari 21 guru yang tidak hadir hanya 4 orang baik dari MI Maupun dari RA Miftahul Jinan. Aspek kebutuhan terhadap program disambut baik oleh para wali kelas, operator dan guru sangat disambut antusias, hal ini dibuktikan dengan semangat para kondisi yang didampingi mengikuti secara aktif dan mampu mempraktikkan ARD dengan hasil yang baik.

\section{E. Kesimpulan}

Pelaksanaan pelatihan pembuatan ARD memberikan dampak positif lembaga dan terhadap wali kelas, guru dan operator, baik dari segi pengetahuan maupun keterampilannya. Hal tersebut terlihat dari hasil tes yang dilakukan di awal dan akhir kegiatan yang menunjukkan peningkatan. Dan dalam segi praktik, para peserta pelatihan telah mampu membuat dengan baik sehingga memberikan pengalaman dan ilmu baru bagi mereka. Pelatihan dan pendampingan kepada para wali kelas, guru dan operator di madrasah Ibtidaiyah dan RA Miftahul Jinan memberikan kontribusi positif dan baik bagi lembaga maupun para sumber daya masyarakat di madrasah yaitu para wali kelas, operator maupun guru. Kedepannya lembaga ini dapat menjadi lembaga yang dapat bersaing dengan lembaga lain dalam ketertiban pembuatan rapor dan input nilai peserta didik.

Setelah pendampingan pembuatan ARD ini diharapakan ada tindak lanjut dari lembaga untuk para wali kelas, operator dan guru, karena setelah pendampingan menunjukkan nilai yang bagus dari para peserta, hal ini juga tidak lain karena tuntutan

31 P. Hadiyanti, “Penerapan strategi pemberdayaan masyarakat melalui program keterampilan produktif di PKBM Rawasari', Jurnal Ilmiah Visi,Vol. 6, No. 2 (2011): 126-135. 
dari lembaga dan pemerintah yang mendesak untuk segera diaplikasikan dalam pembuatan rapor digital (ARD). Selanjutnya, lembaga mampu menjadi sekolah yang mandiri dalam melakukan aplikasi rapor digital stiap semesternya bahkan dalam kenaikan kelas yang menjadi sebuah rutinitas lembaga sebagai evaluasi dari hasil belajar siswa.

\section{Referensi}

Abidin, Yunus. Desain Sistem Pembelajaran dalam Kontek Kurikulum 2013. Bandung: PT. Refika Aditama, 2013.

Hadiyanti, P. "Penerapan strategi pemberdayaan masyarakat melalui program keterampilan produktif di PKBM Rawasari”. Jurnal Ilmiah Visi, 6(2), 2011.

Hosnan. Pendekatan Saintifik dan Konstektual dalam Pembelajaran Abad 21, Kunci Sukses Implementasi Kurikulum 2013. Bogor: Ghalia Indonesia 2014.

Kemdikbud. 2017. Panduan Penggunaan erapor 2017. Online. http//psma.kemdikbud.go.id/.diakses, 22 Oktober 2020..

Keputusan Direktur Jenderal Pendidikan Islam nomor 6003 tahun 2018 tentang Juknis Bimtek ARD Madrasah.

Kunandar. Penilaian Autentik; Penilaian Hasil Belajar Peserta Didik Berdasarkan Kurikulum 2013. Jakarta: PT Rajagrafindo Persada, 2013.

Masruroh, Ninik., dan Umiarso. Modernisasi Pendidikan Islam. Yogyakarta: Ar-Ruzz Media, 2011.

Munardi dan Rahmawati, Selly. Penilaian dalam Kurikulum 2013: Membantu Guru dan Calon Guru Mengetahui Langkah-langkah Penilaian Pembelajaran, Jogjakarta: Andi, 2013.

Nata, Abuddin. Ilmu Pendidikan Islam. Jakarta: Kencana Prenada Media Group. 2010.

O’Brien, Jamers A. dan Marakas, George M. Konsep Dasar: Komponen Sistem Informasi, "Sistem Informasi Manajemen",Edisi 9 - buku 1. Mc Graw Hill Education: Salemba Empat 2014.

Peraturan Menteri Pendidikan dan Kebudayaan Republik Indonesia nomor 65 tahun 2013 tentang Standar Proses Pendidikan Dasar dan Menengah.

Peraturan Menteri Pendidikan Dan Kebudayaan Republik Indonesia Nomor 66 Tahun 2013 Tentang Standar Penilaian Pendidikan.

Permendikbud nomor 66 tahun 2013.

Ranoptri, Deni. Aplikasi Pengolah Nilai Hasil Belajar Siswa Dilengkapi dengan Analisis, dalam https://www.datasekolah.co.id/2015/08/aplikasi-pengolah -nilai-hasilbelajar. html?m=1, diakses tanggal 10 September 2020 . 
Ryan, Damian. Understanding Digital Marketing, Marketing Strategies for Engaging The Digita Generation, London, Philadelphia New Delhi: Kogan Page, 2014, First Edition.

Soetjipto dan Raflis Kosasi, Profesi Keguruan, Jakarta:Rineka Cipta dan Pusat Perbukuan Depdiknas, 2009, cet. IV.

Toffler, Alvin. The Third Wave. New York: William Morrow and Company, Inc, 1980.

Travada, Eko. Aplikasi Pengolahan Nilai Dosen (offline version), dalam https://ekotravada1210.wordpress.com/2011/03/30/aplikasi-pengolahan-nilaiakademik-perguruan- tinggi/, diakses tanggal 10 September 2020.

Widoyoko, Eko Putro. Penilaian Hasil Pembelajaran di Sekolah. Yogyakarta: Pustaka Belajar, 2014.

\section{Wawancara:}

Kepala RA Miftahul Jinan, Wawancara, Sidoarjo, 02 Juli 2020

Kepala MI Miftahul Jinan, Wawancara, Sidoarjo, 03 Juli 2020 